www.jmscr.igmpublication.org

Impact Factor 3.79

ISSN (e)-2347-176x

crossref DOI: _http://dx.doi.org/10.18535/jmscr/v3i9.25

Journal Of Medical Science And Clinical Research

IGM Publication

An Official Publication of IGM Publication

\title{
Risk factors for Osteoporosis in Women Forty Years and Above in Arar City, Kingdom of Saudi Arabia (KSA)
}

Authors

\section{Nagah Mohamed Aboel-Fetoh ${ }^{1}$, Abdelrahman Abukanna ${ }^{2}$, Ahmed Hamad ${ }^{2}$, Hafiz O Ibn Idris ${ }^{2}$; Naglaa Adlan ${ }^{2}$; Shereen M Olama ${ }^{3}$}

${ }^{1}$ Dept of Public Health and Community Medicine, Faculty of Medicine, Sohag University, Sohag, Egypt

${ }^{2}$ Dept of Internal Medicine, Faculty of Medicine, Northern Border University (NBU), Arar, KSA

${ }^{3}$ Dept of rheumatology and Rehabilitation, Faculty of Medicine, Mansoura University, Mansoura, Egypt

Correspondent Author

\section{Abdelrahman Abukanna}

Department of Internal Medicine, Northern Border University

Email: amaabukanna63@hotmail.com, Mobile phones: 00966566309632,fax +146620771

\begin{abstract}
Introduction: Osteoporosis is a systemic skeletal disease characterized by low bone mass and micro architectural deterioration of bone tissue, with a consequent increase in bone fragility and susceptibility to fracture. A high prevalence of osteopenia and osteoporosis were reported in Arab countries.

Objectives: The aim of this study was to assess the risk factors for osteoporosis in women aged 40 years and above in Arar city, KSA.

Methodology: This is a case control hospital based study done in Arar city, KSA. The study population were 202 female patients divided into osteoporosis patients which included 102 female patients aged 40 years and above and the control group included 100 females from the same age group with negative investigations for osteoporosis, the data were collected using a questionnaire and were analysed using SPSS version 15.

Results and Conclusions: Aging, family history, hypertension, endocrine disease, bronchial asthma and cortisone therapy were associated with increased risk of osteoporosis.

Education, employment, habits like sun exposure, take-away meals, supplements and minerals, taking foods like eggs and fish, taking oestrogen replacement therapy and regular exercise were found to be protective against osteoporosis.
\end{abstract}

Keywords: Osteoporosis, osteopenia, menopause, sun exposure, dietary habits, regular exercise.

\section{Introduction}

Osteoporosis is defined as a systemic skeletal disease characterized by low bone mass and micro architectural deterioration of bone tissue, with a consequent increase in bone fragility and susceptibility to fracture (Kanis JA et al 2008). It is widely recognized that osteoporosis represents a major public health problem through its association with fragility fractures (Holroyd $\mathrm{C}$ et al 2008) and (Winsloe $C$ et al 2009). These fractures have physical, psychological, social, and economic consequences that can profoundly influence health-related quality of life (Ioannidis $G$ et al 2008).

Its prevalence is increasing; over 61 million people are expected to have osteoporosis or low 
bone density by 2020, with around $80 \%$ of osteoporosis occurring in women (Lewiecki EM 2004).

Meanwhile, the prevalence of osteoporosis varies from country to country and within countries (Keramat A. et al 2008). Differences in race, nutritional circumstances, level of physical activity, lifestyle, and living conditions all contribute to its variability (de Oliveira Ferreira et al 2009). Several demographic factors may be considered health prevention barriers such as a high rate of illiteracy and low socioeconomic status in developing countries (Navarro MC et al 2009).

Risk factors for osteoporosis in older adults are numerous. The study of osteoporotic fractures, a large, prospective US study, identified 14 clinical risk factors for osteoporotic hip fracture in multivariable models: age, maternal hip fracture, personal history of any fracture from the age of 50, height, poor self-rated health, no weight gain, hyperthyroidism, not

walking for exercise, lack of ambulation, inability to rise from a chair, poor vision, high resting pulse, and current use of benzodiazepines, anticonvulsants, or caffeine (Nayak S et al 2009).

National Osteoporotic foundation, USA and the National consensus group on osteoporosis for the Middle East and North Africa has indicated; menopause, low physical activity, family history of fractures, personal history of fracture as an adult, cigarette smoking, alcohol drinking, thin build, use of oral gluco-corticosteroid therapy for 3 months or more or having history of rheumatoid arthritis, thyroid disease, liver disease as major risk factors for low bone mineral density (BMD) (Maalouf G et al 2007), (National Osteoporosis Foundation 2010) and (Rouzi AA et al 2011).

Among Arab countries, high prevalence of osteopenia and osteoporosis

were reported in Kuwaiti women aged 50 years or more (26.8\% and $9.9 \%$ respectively) (Mahussain $S$ et al 2006) while even higher figures were reported in the Kingdom of Saudi Arabia (KSA) among women of the same age-group, where $31 \%$ had osteopenia, and $40 \%$ had osteoporosis at the lumbar spine ${ }^{14}$.

The aim of this study is to assess the risk factors for osteoporosis in women aged 40 years and above attending the rheumatology and orthopedic clinics at prince Abdul Aziz Bin Musaad hospital and Arar central hospital, Arar city, northern border region K.S.A.

\section{Design and Methods \\ Study area and design:}

This is a case control hospital based study done in rheumatology and orthopedic clinics at prince Abdul Aziz Bin Musaad and Arar central hospitals, Arar city, northern border region, KSA.

\section{Study population:}

The study population were 202 females aged 40 and above which were randomly selected from booked female patients in rheumatology and orthopaedics clinics, divided into102 case group and 100 control group.

The case group included 102 female patients 40 years of age and above whom already diagnosed as having osteoporosis by Dual energy $x$ ray absorptiometry (DXA) scans and measurement of bone mineral density (BMD) and are on follow up in rheumatology and orthopedic clinics. The control group included 100 females from the same age group with negative investigations for osteoporosis.

\section{Data collection}

Written informed consent was obtained after explanation of the aim of the study. The data was collected using a questionnaire including data about sociodemographic status like. Education, occupation and family history of osteoporosis. It also included questions about smoking, the use of takeaway meals, the use of minerals and supplements, history of exposure to sunlight and history of investigations for osteoporosis. The questionnaire also contained questions about common chronic diseases like diabetes mellitus, hypertension, renal disease, cardiac disease, 


\section{JMSCR VoI||3||Issue||9||Page 7461-7468||September}

endocrine disease and other important diseases. It also asked about drug intake including corticosteroids and hormone replacement therapy. The questionnaire also assessed dietary intake of calcium containing products including milk and milk products, eggs, chicken, meat, fish, fruits and vegetables. In addition it assessed the weekly practice of walking, regular exercise and machine exercise. All participants were assessed for weight and height and body mass index was calculated.

\section{Statistical analysis:}

Collected data were coded and analyzed using statistical package for the social sciences (SPSS) version 15 (SPSS Inc. 2005) The w2-test was used as a test of significance, and differences were considered significant at $\mathrm{P}$ value of 0.05 or less.

\section{Ethical considerations}

This study was reviewed and approved by the Research Ethics Committee of Faculty of Medicine, Northern Border University.
Participants were informed that participation is completely voluntary, and written consent was obtained from each participant before being subjected to the questionnaire and after discussing the objective with the participants. No names were recorded on the questionnaires. Adequate training of data collectors took place to ensure protection of confidentiality, and all questionnaires were kept safe.

\section{Results:}

In the socio-demographic characteristics of the study population age and marital status were found to have no significant difference between the study cases and control group, while the level of education had significant effect, most of the cases with osteoporosis are illiterate. It was found that employment was associated with less predisposition to osteoporosis while family history of osteoporosis was associated with increased risk of the disease table(1).

Table (1): Socio-demographic characteristics of the studied women:

\begin{tabular}{|c|c|c|c|c|}
\hline & Case & Control & Total & \multirow{2}{*}{$P$ value } \\
\hline & No $(\%)$ & No $(\%)$ & No $(\%)$ & \\
\hline \multicolumn{4}{|l|}{ Age group } & \multirow{4}{*}{0.825} \\
\hline $40-$ & $54(26.7)$ & $57(28.2)$ & $111(55.0)$ & \\
\hline $50-$ & $19(9.4)$ & $18(8.9)$ & $37(18.3)$ & \\
\hline $60-$ & $29(14.4)$ & $25(12.4)$ & $54(26.7)$ & \\
\hline Mean \pm SD of age & $55.2 \pm 11.1$ & $54.4 \pm 12.2$ & & \\
\hline \multicolumn{4}{|l|}{ Marital status } & \\
\hline Divorced & $8(4.0)$ & $11(5.4)$ & $19(9.4)$ & \multirow{4}{*}{0.63} \\
\hline Married & $75(37.1)$ & $69(34.2)$ & $144(71.3)$ & \\
\hline Single & $1(0.5)$ & $0(.0)$ & $1(.5)$ & \\
\hline Widow & $18(8.9)$ & $20(9.9)$ & $38(18.8)$ & \\
\hline \multicolumn{4}{|l|}{ Educational status } & \multirow{6}{*}{$0.000^{*}$} \\
\hline Illiterate & $71(35.1)$ & $37(18.3)$ & $108(53.5)$ & \\
\hline Preparatory & $5(2.5)$ & $20(9.9)$ & $25(12.4)$ & \\
\hline Read and write & $10(5.0)$ & $15(7.4)$ & $25(12.4)$ & \\
\hline Secondary & $8(4.0)$ & $10(5.0)$ & $18(8.9)$ & \\
\hline University or more & $8(4.0)$ & $18(8.9)$ & $26(12.9)$ & \\
\hline \multicolumn{4}{|l|}{ Occupation } & \multirow{5}{*}{$0.000^{*}$} \\
\hline Employed & $3(1.5)$ & $17(8.4)$ & $20(8.4)$ & \\
\hline House wife & $93(46.0)$ & $65(32.2)$ & $158(78.2)$ & \\
\hline Nurse & $0(.0)$ & $4(2.0)$ & $4(2.0)$ & \\
\hline Teacher & $6(3.0)$ & $14(6.9)$ & $20(9.9)$ & \\
\hline \multicolumn{4}{|c|}{ Family history of osteoporosis } & \multirow{3}{*}{$0.032 *$} \\
\hline No & $80(39.6)$ & $89(44.1)$ & $169(83.7)$ & \\
\hline Yes & $22(10.9)$ & $11(5.4)$ & $33(16.3)$ & \\
\hline
\end{tabular}

$*$ : Significant at $\mathrm{P} \leq 0.05$ 


\section{JMSCR VoI||3||Issue||9||Page 7461-7468||September}

The body mass index and smoking were found to have no effect on the disease while habits including frequent exposure to sun light, taking take away meals and supplements and minerals likely had protective effect against osteoporosis. Most of the studied cases of osteoporosis had not been investigated before for osteoporosis either radiological or blood investigations table(2).

Table (2): BMI, Smoking,Takeaway meals, Supplements and minerals, Exposure to sunlight, History of X ray and Investigations for diagnosis of osteoporosis.

\begin{tabular}{|c|c|c|c|c|}
\hline & Case & Control & Total & \multirow{2}{*}{$P$ value } \\
\hline & No $(\%)$ & No $(\%)$ & No $(\%)$ & \\
\hline \multicolumn{4}{|l|}{ BMI } & \multirow{5}{*}{0.099} \\
\hline Thin & $22(10.9)$ & $12(5.9)$ & $34(16.8)$ & \\
\hline Normal & $36(17.8)$ & $37(18.3)$ & $73(36.1)$ & \\
\hline Overweight & $21(10.4)$ & $33(16.3)$ & $54(26.7)$ & \\
\hline Obese & 23(11.4) & $18(8.9)$ & $41(20.3)$ & \\
\hline Smoking & case & control & & \multirow{4}{*}{$0.001 *$} \\
\hline No & $80(39.6)$ & $77(38.1)$ & $157(77.7)$ & \\
\hline Sometimes & $10(5.0)$ & $0(.0)$ & $10(5.0)$ & \\
\hline Yes & $12(5.9)$ & $23(11.4)$ & $35(17.3)$ & \\
\hline Takeaway meals & case & control & & \multirow{4}{*}{$0.000^{*}$} \\
\hline No & $58(28.7)$ & $64(31.7)$ & $122(60.4)$ & \\
\hline Sometimes & $42(20.8)$ & $2(1.0)$ & $44(21.8)$ & \\
\hline Yes & $2(1.0)$ & $34(16.8)$ & $36(17.8)$ & \\
\hline \multicolumn{4}{|c|}{ Supplements and minerals } & \multirow{4}{*}{$0.000 *$} \\
\hline No & $32(15.8)$ & 19(9.4) & $51(25.2)$ & \\
\hline Sometimes & $23(11.4)$ & $0(.0)$ & $23(11.4)$ & \\
\hline Yes & $47(23.3)$ & $81(40.1)$ & $128(63.4)$ & \\
\hline \multicolumn{4}{|c|}{ Exposure to sunlight } & \multirow{4}{*}{$0.000^{*}$} \\
\hline No & $32(15.8)$ & $18(8.9)$ & $50(24.8)$ & \\
\hline Sometimes & $34(16.8)$ & $10(5.0)$ & $44(21.8)$ & \\
\hline Yes & $36(17.8)$ & $72(35.6)$ & $108(53.5)$ & \\
\hline \multicolumn{4}{|c|}{ History of X ray for diagnosis of osteoporosis } & \multirow[t]{3}{*}{$0.000^{*}$} \\
\hline No & $98(48.5)$ & $61(30.2)$ & $159(78.7)$ & \\
\hline Yes & $4(2.0)$ & $39(19.3)$ & $43(21.3)$ & \\
\hline \multicolumn{4}{|c|}{ History of doing Investigations for diagnosis of osteoporosis } & \multirow[t]{3}{*}{$0.004^{*}$} \\
\hline No & \begin{tabular}{|l}
$44(21.8)$ \\
\end{tabular} & $24(11.9)$ & $68(33.7)$ & \\
\hline Yes & \begin{tabular}{|l|}
$58(28.7)$ \\
\end{tabular} & $76((37.6)$ & $134(66.4)$ & \\
\hline
\end{tabular}

*: Significant at $\mathrm{P} \leq 0.05$

The association between chronic diseases and osteoporosis was studied and it was found that diabetes mellitus, cardiac diseases and renal disease had no significant association while hypertension and endocrine diseases had significant association. In addition taking corticosteroids was associated with increased risk for osteoporosis while taking hormonal replacement therapy was associated with less cases of osteoporosis table(3).

Table (3): chronic diseases and regular drugs intake in the studied women:

\begin{tabular}{|c|c|c|c|c|c|}
\hline Disease & Case & Control & Total & OR & \multirow{2}{*}{$P$ value } \\
\hline DM & No $(\%)$ & No (\%) & No $(\%)$ & \multirow{3}{*}{1.07} & \\
\hline No & $66(32.7)$ & $63(31.2)$ & $129(63.9)$ & & \multirow{2}{*}{0.458} \\
\hline Yes & $36(17.8)$ & $37(18.3)$ & $73(36.1)$ & & \\
\hline \multicolumn{4}{|c|}{ Hypertension } & \multirow{3}{*}{1.91} & \multirow{3}{*}{0.019} \\
\hline No & $56(27.7)$ & $70(34.7)$ & $126(62.4)$ & & \\
\hline Yes & $46(22.8)$ & \begin{tabular}{|l|}
$30(14.9)$ \\
\end{tabular} & $76(37.6)$ & & \\
\hline
\end{tabular}




\begin{tabular}{|c|c|c|c|c|c|}
\hline \multicolumn{4}{|c|}{ Renal troubles } & \multirow{3}{*}{3.61} & \multirow{3}{*}{0.09} \\
\hline No & $95(47.0)$ & $98(48.5)$ & 193(95.5) & & \\
\hline Yes & $7(3.5)$ & $2(1.0)$ & $9(95.5)$ & & \\
\hline \multicolumn{4}{|c|}{ Cardiac disease } & \multirow{3}{*}{1.06} & \multirow{3}{*}{0.52} \\
\hline No & $88(43.6)$ & $87(43.1)$ & $175(86.6)$ & & \\
\hline Yes & $14(6.9)$ & $13(6.4)$ & $27(13.4)$ & & \\
\hline \multicolumn{4}{|c|}{ Endocrine disease } & \multirow{3}{*}{18.41} & \multirow{3}{*}{$0.00 *$} \\
\hline No & $86(42.6)$ & $99(49.0)$ & $185(91.6)$ & & \\
\hline Yes & $16(7.9)$ & $1(0.5)$ & $17(8.4)$ & & \\
\hline \multicolumn{4}{|c|}{ Other important diseases } & \multirow{3}{*}{4.31} & \multirow{3}{*}{$0.01 *$} \\
\hline No & $90(44.6)$ & $97(48.0)$ & $187(92.6)$ & & \\
\hline Yes & $12(5.9)$ & $3(1.5)$ & $15(7.4)$ & & \\
\hline \multicolumn{4}{|c|}{ Cortisone therapy } & \multirow{3}{*}{1.39} & \multirow{3}{*}{0.283} \\
\hline No & $87(43.1)$ & $89(44.1)$ & $176(87.1)$ & & \\
\hline Yes & $15(7.4)$ & $11(5.4)$ & $26(12.9)$ & & \\
\hline \multicolumn{4}{|c|}{ Hormone replacement therapy } & \multirow{3}{*}{0.26} & \multirow{3}{*}{$0.002 *$} \\
\hline No & $95(47.0)$ & $78(38.6)$ & 173(85.6) & & \\
\hline Yes & $7(3.5)$ & $22(10.9)$ & $29(14.4)$ & & \\
\hline
\end{tabular}

*: Significant at $\mathrm{P} \leq 0.05$

Food items which have been studied include milk association with osteoporosis except eggs which and milk products, meat, chicken, eggs, fish, fruits have significant association table(4). and vegetable and all are found to have low

Table (4): weekly intake of food items which have a preventive role in osteoporosis in the studied women:

\begin{tabular}{|c|c|c|c|c|c|c|c|c|c|}
\hline \multicolumn{2}{|l|}{ Food item } & $\begin{array}{l}0 \\
\text { time/we } \\
\text { ek }\end{array}$ & $\begin{array}{l}1 \\
\text { time/wee } \\
\mathrm{k}\end{array}$ & $\begin{array}{l}2 \\
\text { times/we } \\
\text { ek }\end{array}$ & $\begin{array}{l}3 \\
\text { time/wee } \\
\mathrm{k}\end{array}$ & $\begin{array}{l}4 \\
\text { times/we } \\
\text { ek }\end{array}$ & Total & $\begin{array}{l}\text { Mean } \\
\pm \mathrm{SD}\end{array}$ & $\mathrm{P}$ value \\
\hline & & No.(\%) & No.(\%) & No.(\%) & No.(\%) & No.(\%) & No.(\%) & & \\
\hline \multirow{2}{*}{$\begin{array}{l}\text { Milk \& milk } \\
\text { products }\end{array}$} & case & $2(1.0)$ & $13(6.4)$ & 21(10.4) & $28(13.9)$ & $38(18.8)$ & $102(50.5)$ & $2.8 \pm 1.1$ & \multirow[t]{2}{*}{0.12} \\
\hline & control & $0(.0)$ & $6(3.0)$ & $17(8.4)$ & $25(12.4)$ & $52(25.7)$ & $100(49.5)$ & $3.2 \pm 0.9$ & \\
\hline \multirow[t]{2}{*}{ egg } & case & $7(3.5)$ & $15(7.4)$ & $18(8.9)$ & $29(14.4)$ & $33(16.3)$ & $102(50.5)$ & $2.6 \pm 1.2$ & \multirow[t]{2}{*}{$0.001 *$} \\
\hline & control & $1(.5)$ & $4(2.0)$ & 19(9.4) & $21(10.4)$ & $55(27.2)$ & $100(49.5)$ & $3.2 \pm 0.9$ & \\
\hline \multirow[t]{2}{*}{ chicken } & case & $1(.5)$ & $5(2.5)$ & $6(3.0)$ & $5(2.5)$ & $85(42.1)$ & $102(50.5)$ & $3.6 \pm 0.8$ & \multirow[t]{2}{*}{0.21} \\
\hline & control & $0(.0)$ & $5(2.5)$ & $3(1.5)$ & $13(6.4)$ & 79(39.1) & $100(49.5)$ & $3.6 \pm 0.7$ & \\
\hline \multirow[t]{2}{*}{ meat } & case & $8(4.0)$ & $41(20.3)$ & $32(15.8)$ & $10(5.0)$ & $11(5.4)$ & $102(50.5)$ & $1.7 \pm 1.0$ & \multirow[t]{2}{*}{0.30} \\
\hline & control & $4(2.0)$ & $44(21.8)$ & $29(14.4)$ & $17(8.4)$ & $6(3.0)$ & $100(49.5)$ & $1.7 \pm 0.9$ & \\
\hline \multirow[t]{2}{*}{ fish } & case & $19(9.4)$ & $66(32.7)$ & $10(5.0)$ & $1(.5)$ & $6(3.0)$ & $102(50.5)$ & $1.1 \pm 0.9$ & \multirow[t]{2}{*}{0.05} \\
\hline & control & $10(5.0)$ & $65(32.2)$ & $19(9.4)$ & $4(2.0)$ & $2(1.0)$ & $100(49.5)$ & $1.2 \pm 0.7$ & \\
\hline \multirow[t]{2}{*}{ fruits } & case & $6(3.0)$ & $21(10.4)$ & $21(10.4)$ & $23(11.4)$ & $31(15.3)$ & $102(50.5)$ & $2.5 \pm 1.2$ & \multirow[t]{2}{*}{0.19} \\
\hline & control & $1(.5)$ & $24(11.9)$ & $29(14.4)$ & $16(7.9)$ & $30(14.9)$ & $100(49.5)$ & $2.5 \pm 1.1$ & \\
\hline \multirow[t]{2}{*}{ vegetables } & case & $0(0.0)$ & $12(5.9)$ & $24(11.9)$ & $17(8.4)$ & $49(24.3)$ & $102(50.5)$ & $3.0 \pm 1.0$ & \multirow[t]{2}{*}{0.17} \\
\hline & control & $0(0.0)$ & b) & $19(9.4)$ & ) & $52(25.7)$ & $100(49.5)$ & 9 & \\
\hline
\end{tabular}

*: Significant at $\mathrm{P} \leq 0.05$

The effect of walking, regular exercise and machine exercise was beneficial for protection against osteoporosis especially regular exercise table(5). 
Table (5): weekly practice of walking and muscular exercises in the studied women:

\begin{tabular}{|c|c|c|c|c|c|c|c|c|c|}
\hline & $\begin{array}{l}0 \\
\text { time/week }\end{array}$ & $\begin{array}{l}1 \\
\text { time/week }\end{array}$ & $\begin{array}{l}2 \\
\text { times/week }\end{array}$ & $\begin{array}{l}3 \\
\text { time/week }\end{array}$ & $\begin{array}{l}4 \\
\text { times/week }\end{array}$ & Total & $\begin{array}{l}\text { Mean } \\
\pm \mathrm{SD}\end{array}$ & $\begin{array}{l}\mathrm{P} \\
\text { value }\end{array}$ \\
\hline & & No.(\%) & No.(\%) & No.(\%) & No.(\%) & No.(\%) & No.(\%) & & \\
\hline \multirow{2}{*}{ Walking } & case & $12(5.9)$ & $22(10.9)$ & $16(7.9)$ & $16(7.9)$ & $36(17.8)$ & $102(50.5)$ & $2.4 \pm 1.4$ & \multirow[t]{2}{*}{0.46} \\
\hline & control & $14(6.9)$ & $12(5)$. & $15(7.4)$ & $17(8.4)$ & $42(20.8)$ & $100(49.5)$ & $2.6 \pm 1.4$ & \\
\hline \multirow{2}{*}{$\begin{array}{l}\text { Regular } \\
\text { exercise }\end{array}$} & case & $78(38.6)$ & $10(5)$. & $9(4.5)$ & $4(2.0)$ & $1(0.5)$ & $102(50.5)$ & $0.4 \pm 0.8$ & \multirow[t]{2}{*}{$0.000 *$} \\
\hline & control & $49(24.3)$ & 13(6.) & $14(6.9)$ & $10(5.0)$ & $14(6.9)$ & $100(49.5)$ & $1.2 \pm 1.4$ & \\
\hline \multirow{2}{*}{$\begin{array}{l}\text { Machine } \\
\text { exercise }\end{array}$} & case & $94(46.5)$ & $3(1.5)$ & $2(1.0)$ & $2(1.0)$ & $1(0.5)$ & $102(50.5)$ & $0.2 \pm 0.6$ & \multirow[t]{2}{*}{0.52} \\
\hline & control & $85(42.1)$ & $7(3.5)$ & $3(1.5)$ & $2(1.0)$ & $3(1.5)$ & $100(49.5)$ & $0.3 \pm 0.8$ & \\
\hline
\end{tabular}

*: Significant at $\mathrm{P} \leq 0.05$

\section{Discussion}

In this study the age of study population was between 40 and 69 years which have the same effect on both case and control groups. This age is known to be associated with increased risk for osteopenia and osteoporosis compared to young age, this was also documented by the study done at King Saud University in Riyadh, KSA by Samira et al 2014. Pathophysiology of aging in women indicates disconnection of trabecular network leading to reduction in bone mineral, structural deterioration and decrease in bone strength which may explain the increase in prevalence of low bone mineral density by $5 \%$ for each ten-year period between 40 and 50 years and 50 to 60 years. Old age effects on bones are further aggravated by estrogen deficiency due to menopause (El-Desouki MI et al 2003), (Mantila RSM et al 2012).

Marital status was also found to have the same effect on both groupsin our study with no significant difference between the two groups ( $p$ value is 0.63 ), but women who were educated and employed had significant lower prevalence of osteoporosis ( $p$ value is 0.00 ) possibly because they were more exposed to sun light and were aware of the importance of vitamin $\mathrm{D}$, calcium and other minerals for healthy bones. The same results were obtained by AlJohara and her research group in Riyadh, KSA (2014) and Luong ML and his group(2012).

Family history of osteoporosis was found to be a significant predisposing factor for osteoporosis in our study ( $\mathrm{p}$ value is 0.03 ) possibly due to the presence of familial causes. The same result was also found by Jose' Antonio in Spain (2011).
In this study the body mass index was found to have no effect on the disease, but other studies found significant effect of low BMI (De Laet C et al 2005). Habits including frequent exposure to sun light, take away meals and supplements and minerals were found to have protective effect against osteoporosis as these provide calcium, Phosphorous and vitamin D which were essential for physiology of normal bones. The same results were found in a study done by Afsaneh Keramat in Iran (2008). He also found that smoking have no effect on osteoporosis as in our study.

The effect of common chronic diseases as predisposing factors for osteoporosis was found to be significant in case of hypertension, endocrine disease and bronchial asthma while there is no obvious effect in case of diabetes mellitus, renal disease and cardiac disease (table 3) although ElHeis and his group (2013) in Jordan found significant association of these diseases with osteoporosis.

The study showed that taking cortisone therapy was found to increase the risk for osteoporosis while hormonal replacement therapy like estrogen was found to have protective effect against osteoporosis. The same results were obtained by other researchers (Afsaneh Keramat et al 2008), (E. A. Petri Nahas et al 2011).

Dietary habits of taking food rich in calcium was found to be protective against osteoporosis in this study, these include eggs and fish which were statistically significant ( $\mathrm{p}$ values were 0.00 and 0.05 ) in addition to milk and milk products, meat, chicken, fruits and vegetables which did not reach the statistical significance( $p$ value $>0.05)$, other researchers found the same results (Samira $\mathrm{M}$ et al 
2014), (AlJohara et al2014), (Jose' Antonio et al2011), (Afsaneh Keramat et al 2008) and (Maryam Rafraf et al 2011).

Regular exercise was found to be statistically significant in preventing osteoporosis compared to walking and machine exercise ( $\mathrm{p}$ value 0.00 ). The same result was obtained by other researchers (Afsaneh Keramat et al 2008), (Dalsky Gp et al 1988) and (Bass S et al 1998). Weight bearing exercise and muscle contraction combined have been shown to effectively increase bone density in the spine. It is recommended that an individual perform 20 to 30 minutes of aerobic exercise 3 to 4 times weekly to increase bone mass. Simple exercises such as walking can help strengthen bones and muscles and there is strong evidence that physical activity begun early in life contributes to higher peak bone mass (Dhuper Set al 1998) (Fauci B et al 2012).

\section{Conclusions}

Aging, family history, hypertension, endocrine disease, bronchial asthma and cortisone therapy was associated with increased risk of osteoporosis. Education, employment, habits like sun exposure, taking take away meals and supplements and minerals, taking foods like eggs and fish, taking estrogen replacement therapy and regular exercise were found to be protective against osteoporosis.

\section{Acknowledgements}

We would like to thank the medical students Duaa Mohamed Alsharari and Modhi Alhadi Alanazi for their great help in distribution of the questionnaire and collection of data.

\section{References}

1. Afsaneh Keramat et al, The assessment of osteoporosis risk factors in Iranian women compareed with Indian women, BMC Musculoskelet Disord. 2008; 9: 28. Published online 2008 Feb 27. doi:10.1186/1471-2474-9-28.

2. AlJohara et al, Prevalence and factors associated with low bone mineral density in Saudi women: a community based survey. MC
Musculoskelet Disord. 2014; 15: 5.Published online 2014Jan8. doi:10.1186/1471-2474-15-5

3. Bass S, Pearce G, Brudney M, hendrich E, DelmasPd, Handring A. Exercises before puberty may confer residual benefit in bone density in adulthood. Studies in active pre pubertal and retired female gymnasts. Journal of Bone and Mineral Research. 1998;13:500 7. doi: 10.1359/jbmr.1998.13.3.500. [PubMed] [Cross Ref].

4. Dalsky Gp, Stoke Ks, Ehsani AA, statopolsky E, Lee Wc, BirgeSj., Jr weight-bearing exercises training and lumbar bone mineral content in post-menopausal women. Annals of Internal Medicine. 1988:824-8.[PubMed]

5. De Laet $\mathrm{C}$ et al. Body mass index as a predictor of fracture risk: a meta-analysis. Osteoporosis Int, 2005, 16:1330-1338.

6. De Oliveira Ferreira N, Arthuso M, da Silva R, Pedro AO, Neto AM, Costa-Paiva L. Quality of life in women with postmenopausal osteoporosis: correlation between QUALEFFO 41 and SF-36. Maturitas 2009;20:85-90.

7. Dhuper S, Warren MP, Brooks J-Gunn, Fox R. Effects of hormonal status on bone density in adolescent girls. Journal of clinical endocrinology and metabolism. 1990;71:1083-8. [PubMed]

8. E. A. Petri Nahas, M. S. Kawakami, J. NahasNeto, D. de AraujoButtros, L. Cangussu and A. B. Rodrigues. Assessment of risk factors for low bonemineral density in Brazilian postmenopausal women. CLIMACTERIC 2011;14:220-227.

9. El-Desouki MI. Osteoporosis in postmenpausal Saudi women using dual x-ray bone densitometry. Saudi Med J 2003;24:953-6.

10. Fauci B, Longo K, Hauser, Kasper, Jameson and Loscalzo. Harrison's Principles Of Internal Medicine. 18. McGraw-Hill; 2012.

11. Holroyd C, Cooper C, Dennison E. Epidemiology of osteoporosis. Best Pract Res Clin EndocrinolMetab 2008; 22:671-685.

12. Ioannidis G, Thabane L, Gafni A, Hodsman A, Kvern B, Johnstone D, Plumley N, Salach L, 
Jiwa F, Adachi JD, Papaioannou A. Optimizing care in osteoporosis: The Canadian quality circle project. BMC MusculoskeletDisord 2008;9:130.

13. Jose' Antonio Martínez Pe' rez, Santiago Palacios, Felipe ChavidaGarci'a, \&MaitePe' rez.Assessing osteoporosis risk factors in Spanish menopausal women. Gynecological Endocrinology, Oct 2011;27(10):807-813.

14. Kanis JA, Burlet N, Cooper C, Delmas PD, Reginster JY, Borgstrom F, Rizzoli R. European guidance for the diagnosis and management of osteoporosis in postmenopausal women. Osteoporos Int 2008;19:399-428.

15. Keramat A, Patwardhan B, Larijani B, Chopra A, Mithal A, Chakravarty D, Adibi H, Khosravi A. The assessment of osteoporosis risk factors in Iranian women compared with Indian women. BMC MusculoskeletDisord 2008;9:28-37.

16. Lewiecki EM. Management of osteoporosis. Clin Mol Allergy 2004;2:9-19.

17. Luong ML, Cleveland RJ, Nyrop KA, Callahan LF. Social determinants and osteoarthritis outcomes.Aging health. 2012;8 :413-437. doi: 10.2217/ahe.12.43. [PMC free article] [PubMed][Cross Ref]

18. Maalouf G, Gannagé-Yared MH, Ezzedine J. et al. Lebanese osteoporosis prevention society, Shariati hospital, Iran. Middle East and North Africa consensus on osteoporosis. J Musculoskelet Neuronal Interact. 2007;7:131143. [PubMed]

19. M.A. El-Heis, E.A. Al-Kamil, K.A. Kheirallah, T.N Al-Shatnawi, M. Gharaibia and A. Al-Mnayyis. Factors associated with osteoporosis among a sample of Jordanian women referred for investigation for osteoporosis. EMHJ.V.19 No.5.2013.459-464.

20. Mahussain S, Badr H, Al-Zaabi K, Mohammad M, Alnafisi N. Bone mineral density in healthy Kuwaiti women. Arch Osteoporos2006;1:51-7.

21. Mantila RSM, Hurd AL, Xu H, Fuchs RK, Warden SJ. Age related changes in proximal humerus bone health in healthy, white males. Osteoporos Int. 2012;23:2775-2783. doi: 10.1007/s00198-012-1893-1.[PMC free article] [PubMed] [Cross Ref].

22. Maryam Rafraf and BehnazBazyun. Food Habits Related To Osteoporosis in Women in Iran. PMCID: PMC3963621. Published online 2011 Dec 20. doi: 10.5681/hpp.2011.012.

23. National Osteoporosis Foundation. Clinician's Guide to prevention and treatment of osteoporosis.Washington, DC: National Osteoporosis Foundation; 2010. Accessed from : http://www.nof.org/files/nof/public /content/file/344/upload/159.pdf.

24. Navarro MC, Sosa M, Saavedra P, Lainez P, Marrero M, Torres M, Medina CD. Poverty is a risk factor for osteoporotic fractures. Osteoporos Int 2009;20:393-398.

25. Nayak S, Roberts MS, Greenspan SL. Factors associated with osteoporosis screening and recommendations for osteoporosis screening in older adults. J Gen InternMed 2009;24:585591.

26. Rouzi AA, Al Sibiani SA, Al Senani NS, Radaddi RM, Aradawi MS. Independent predictors of all osteoporosis related fractures among healthy Saudi postmenopausal women :the CEOR study. Bone.2012;50:713-722. doi:10.1016/j.bone.2011.11.024.[PubMed][Cr oss Ref]

27. Samira M. Mahboub,May N. AlMuammar, Azza A. Elareefy.Evaluation of the Prevalence and Correlated Factors for Decreased Bone Mass Density among Preand Post-menopausal Educated Working Women in Saudi Arabia. J Health PopulNutr. 2014 Sep; 32(3): 513-519.

28. SPSS Inc. Statistical package for the social sciences (SPSS), version 15.0. Chicago, IL, USA: SPSS Inc.; 2005.

29. Winsloe C, Earl S, Dennison EM, Cooper C, Harvey NC. Early life factors in the pathogenesis of osteoporosis. CurrOsteoporos Rep 2009;7:140-144. 